\title{
Currency Substitution and Money Demand in Euroland
}

\author{
MIGUEL LEBRE DE FREITAS*
}

\begin{abstract}
This paper tests the stability of the demand for money in the euro-area in the context of an open economy. A sample consisting of quarterly data covering the 1982:2-1999:3 period is considered. The main finding is that the U.S. dollar long-term interest rate plays a significant role in the European money demand relationship. This result holds for different combinations of variables forming the vector auto-regressive system and suggests that international monetary interdependency may be an important factor influencing the ECB monetary policy. (JEL E41, E58, F41)
\end{abstract}

Keywords: EMU, money demand, international currencies, currency substitution

\section{Introduction}

In recognition of the fundamentally monetary origins of inflation, the European Central Bank (ECB) assigned a 'prominent role for money' [ECB, 1999; Issing, 2000]. Money is viewed as the nominal anchor of the Euro-system and the First Pillar of the ECB strategy. This prominent role is signalled by the announcement of a quantitative 'reference value' for the growth rate of the broad monetary aggregate M3. Such 'reference value' does not have the strength of an intermediate target. Lack of controllability of the money supply over the short-run, uncertainty concerning the transmission mechanism in the Eurosystem, and the recognition that the launch of the euro would represent a significant structural break lead the ECB to adopt instead a weak type of money targeting, in which there is no commitment to correct deviations over the short-term. In addition, a Second Pillar ('a general assessment of price stability based on a wide range of indicators') was formulated, opening a window to less orthodox approaches to price stability. The indicators considered in the second pillar include, for example, the exchange rate, wages, the yield curve, measures of real activity, business and consumer surveys, as well as macroeconomic projections and forecasts. The ECB framework reflects, thus, a balance between continuity with the Bundesbank tradition, so as to inherit credibility, and flexibility, as required to operate in the global environment.

Either as source of information or as intervention indicator, money has a significant role in the ECB policy formulation. Not surprisingly, the stability and the information content of EU-wide monetary aggregates became a very topical issue in the research agenda [some references below; for a survey see Browne et al., 1997]. The research

*Universidade de Aveiro and NIPE - Portugal. This paper draws on an earlier version and was prepared while the author was at the Bank of Portugal (the usual disclaimer applies). It was presented at the 2003 Meeting of the Economic Modelling Network. The author acknowledges Luis Catela Nunes, Carlos Santos, Carlos Robalo Marques, Nuno Alves, and an anonymous referee for their helpful suggestions. 
benefited from the rapid development in the cointegration literature, which has raised the possibility of models combining traditional steady-state functions with complex short-term dynamics to be reasonably stable over periods of substantial institutional change. In general, empirical exercises addressing the stability and the information content of monetary aggregates in the euro-area have been able to identify stable money demand relationships. A controversy exists, however, as to whether such stability is applicable to forecasting purposes. Indeed, since empirical studies have been based on constructed pre-EMU monetary aggregates, their validity has been questioned both in light of the Lucas critique and aggregation bias [Beyer et al., 2001; Arnold and de Vries, 2000; Fagan and Henry, 1999; Hayo, 1999; Spencer, 1997; Arnold, 1994].

This paper questions the literature on the euro-area money demand from a different angle. In a financial environment marked by absence of capital controls and growing international portfolio diversification, the agents' ability to shift the location and the currency denomination of their asset holdings may have a destabilising impact on money demands. If the demand for money in Europe responds to monetary developments in the U.S., then the rate of money growth in the euro-area may become a poor indicator of risks to price stability. To this aim, we estimate a money demand system for the euroarea using the Johansen-Juselius maximum likelihood technique. Monetary interdependence is assessed investigating the significance of a U.S. dollar interest rate in the long-run relationship describing the demand for money in the euro-area. This procedure is consistent with the currency substitution hypothesis in the context of complete bond markets, as demonstrated by Thomas [1985]. Previous tests for the currency substitution hypothesis using this approach include Bergstrand and Bundt [1990] and Mizen and Pentecost [1994]. Experimenting with alternative combinations of variables in the Vector Auto-regression (VAR) system, we consistently obtain a significant and positive coefficient for the U.S. long-term interest rate in the long-run relationship describing the euro-area money demand. This evidence suggests that currency substitution (or, in a broader interpretation, international monetary interdependence) may be an important factor influencing the ECB monetary policy.

Monetary interdependence and currency substitution (CS) became central issues in monetary economics and should increase in importance in the future. As pointed out by Masson [2000], technology and globalisation are blurring the distinction between national and international uses of money, opening channels through which domestic money markets are exposed to shocks occurring abroad. This is a matter of concern for policymakers, as it rises the unpredictability of the money demand and reduces the effectiveness of monetary policy, even under flexible exchange rates [the implications of CS are discussed, for example, in Miles, 1978; Kareken and Wallace, 1981; McKinnon, 1982; Lebre de Freitas, 2004; for a survey, see Giovannini and Turtelboom, 1994]. In Europe, the CS debate was revived during the transition to EMU, giving rise to the socalled 'indirect approach to CS' [see Artis, 1996, for a survey]. Following this literature as capital controls were phased out in individual member states, residents' demand for monetary assets became increasingly influenced by European variables, raising the question as to whether stable money demand functions could be estimated at the national level. As long as foreign money holdings were denominated in European currencies, however, internalisation could be achieved by aggregating up [the argument backs from McKinnon, 1982]. This question was addressed by Bekx and Tullio [1989], Kremers and Lane [1990], Bayoumi and Kenen [1993], Cassard et al. [1994] and Spencer [1997], who found that EU-wide monetary aggregates are indeed more stable and/or more helpful to predict national inflation rates than the correspondent national 
aggregates. This evidence revived the confidence on the role of quantitative money targets and favoured the view that the ECB would be able to implement monetary policy more effectively than individual central banks. ${ }^{1}$

A different question is whether CS vis-à-vis the U.S. dollar remains as a potential source of instability. This question was subject to scrutiny in the first wave of estimates addressing EU-wide monetary aggregates [Bekx and Tullio, 1989; Kremers and Lane, 1990; Monticelli and Strauss-Kahn, 1993; Artis, 1996]. In this literature, CS is tested by the significance of a variable capturing the expected exchange rate depreciation in the money demand equation. Compared with our approach, this procedure has two limitations: First, it is not based on a well founded microeconomic theory of money demand; second, the CS hypothesis is assessed on the basis of a variable that is not observable, namely the expected exchange rate depreciation. The proxies used were the long-term interest rate differential in Bekx and Tullio [1989]; the dollar-ECU nominal exchange rate in Kremers and Lane [1990]; the actual exchange rate depreciation in Monticelli and Strauss-Kahn [1993]; and the dollar-ECU real exchange rate in Artis [1996]. Regardless the quality of the proxies used, it is remarkable that in all these studies the respective coefficient was found to be significant. It is, thus, surprising that the most recent money demand estimates for the euro-area [Brand and Cassola, 2004; Coenen and Vega, 2001; Funke, 2001; Fagan and Henry, 1999; Fase and Winder, 1998; Spencer, 1997] have been entirely devoted to the closed economy portfolio balance model.

\section{Theoretical Considerations}

In the CS literature, two main approaches have been followed: The Portfolio Balance Model (PBM) [Cuddington, 1983; Branson and Henderson, 1985] and the Liquidity Services Model (LSM) [Miles, 1978; Thomas, 1985, Lebre de Freitas and Veiga, 2006]. The PBM follows the aggregative tradition of postulating money demand functions that depend positively on a scale variable, such as income or wealth, and negatively on the return of each alternative asset. In a context in which money and bonds denominated in domestic and foreign currency are both available, the demand for domestic money becomes a negative function of the domestic interest rate, the foreign interest rate, and the expected exchange rate depreciation. The later influences the money demand by two different channels: Substitutability vis-à-vis the foreign money (CS) and substitutability vis-à-vis the foreign bond (capital flight). For this reason, followers of the PBM have claimed that a negative influence of an expected exchange rate depreciation term in the demand for domestic money does not necessarily provide evidence of CS [see Cuddington, 1983, for details].

The PBM has two main shortcomings. First, as noted by Branson and Henderson [1985], gross substitutability between all assets is not always consistent with individual optimisation. Second, this approach is not capable of explaining why money is held when dominated by interest-bearing assets. A closer scrutiny of the properties of the money demand in light of firmer microeconomic foundations was made by Thomas [1985]. Assuming that money reduces transaction costs, this author demonstrated that borrowing and lending opportunities separate the ownership of monies from portfolio decisions. ${ }^{2}$ Since money bears the same characteristics as (same currency) bonds and earns a lower return, it should not be held in the portfolio for the speculative and riskdiversification reasons that underlie the demand for financial assets in general. Domestic and foreign money holdings are selected solely to satisfy transaction needs. Thus, on one hand, the individual selects her money holdings based on each money liquidity services 
and user costs; on the other hand, she borrows or lends to achieve an optimal denomination structure for the overall portfolio, that shall reflect a balance between expected returns and risk. An optimal currency hedge is created and the denomination structure of the individual portfolio is independent of the choice among monetary assets. Opportunity cost variables influencing portfolio asset demands in general, including the expected inflation rate and the expected exchange rate depreciation fail to influence money demands, as long as they are not embedded in the nominal interest rates.

The Thomas' model was implemented empirically to investigate the existence of CS among major currencies [Bergstrand and Bundt, 1990; Mizen and Pentecost, 1994]. The empirical model used is:

$$
m_{t}=\beta_{0}+\beta_{1} i_{t}+\beta_{2} j_{t}+\beta_{3} y_{t}+u_{t},
$$

where $m$ is the log of real money balances, $i$ and $j$ are the nominal interest rates on domestic and foreign bonds, respectively, $y$ is the log of real income, $u$ is a random error term, and $t$ is a time index. The expected signs are $\beta_{1}<0, \beta_{2} \geq 0$, and $\beta_{3}>0$. The CS hypothesis is assessed by the sign and significance of $\beta_{2}$ : If the two currencies are substitutes, a decline in the user cost of foreign money will induce a cash switching from domestic money to foreign money.

Recent estimates for the money demand in the euro-area may be interpreted as imposing $\beta_{2}=0$ in equation (1) [Brand and Cassola, 2004; Coenen and Vega, 2001; Funke, 2001; Hayo, 1999; Fagan and Henry, 1999; Spencer, 1997]. In the exercise below, this restriction is subject to a statistical scrutiny: If it holds, then the CS hypothesis is rejected. Under uncovered interest rate parity, this would be equivalent to a testing for CS by investigating the significance of an expected depreciation term in a linear transformation of equation (1). Sticking with equation (1), however, one has the advantages of not imposing such an assumption and of relying only on observed variables.

\section{Variables and Data Used}

Vector error correction models account for both long-run relationships and shortterm dynamics. Variables not playing a role in the long-run relationship may still have a role in the dynamic adjustment of the system to the long-run equilibrium. For this reason, the estimation exercise below includes variables other than those appearing in the money demand equation (1). These are: The euro-area inflation rate $(\pi)$ and the euroarea money market rate $(s)$.

Recent estimates for the euro-area have considered the inflation rate $(\pi)$ as an argument of the money demand function [Fase and Winder, 1998]. In light of the PBM, this parameter captures substitutability between money and real assets. In light of the LSM, the ownership of monetary assets is separable from portfolio decisions, so that the inflation rate should not appear in the money demand equation. Still, in a dynamic formulation, the inflation rate may have a role in correcting the short-term deviations between the real value of $\mathrm{M} 3$ and the desired demand, as implied by its determination at each moment. The recent evidence with euro-area aggregates suggests that this variable, although enriching the short-term dynamics of the model, may be dropped from the longrun money demand relationship to identify an orthogonal relationship, together with the long-term interest rate [Brand and Cassola, 2004; Coenen and Vega, 2001]. A similar approach will be followed in the estimation below. 
In Funke [2001] and in Cassard et al. [1994], the short-term interest rate $(s)$ is modelled as the opportunity cost of money. Hence, its coefficient in the money demand equation is expected to be negative. Fase and Winder [1998] and Coenen and Vega [2001] interpret instead the short-term interest rate as a proxy for the M3 own return, thus, expecting a positive coefficient. However, the evidence has not been favourable to this second approach. As noted by Brand and Cassola [2004, p. 820], although the short-term interest rate and the own rate of M3 exhibit similar trends, their dynamics are quite different. Given this, the most recent practice - when both the short- and the long-term interest rates are included in the VAR system - has been to drop the former from the long-run money demand relationship and use it to identify a co-integrating vector capturing the slope of the yield curve [Brand and Cassola, 2004; Coenen and Vega, 2001]. In order to account for this possibility, the euro-area short-term interest rate is included in some of the systems considered below.

The study uses quarterly data, from 1982:2 to 1999:3. ${ }^{3}$ The variables used are the log of the (seasonally adjusted) real M3 in the euro-area $(\mathrm{m})$, the log of real GDP in the euro-area $(y)$, the euro-area inflation rate $(\pi)$, the three-month money market interest rate in the euro-area $(s)$, the 10-year government bonds yields in the euro-area $(i)$, and the 10-year government bonds yields in the U.S. $(j)$. All European variables are from the ECB database, as displayed in Brand and Cassola [2004]. The U.S. dollar interest rate is from the International Financial Statistics.

\section{Estimation Results}

Table 1 reports the estimation results for different VAR systems corresponding to different combinations of variables, as described in the legend (unit root tests indicating that all variables are non-stationary are available from the author upon request). Since imposing $\beta_{2}=0$ in the long-run money demand relationship is not the same as estimating the system without the foreign interest rate among the regressors, we also display the estimation results of systems in which the foreign interest rate is omitted (systems 1, 3, 5 in Table 1). This will allow the reader to evaluate the uncertainty concerning the estimates.

Estimates are obtained using the Johansen-Juselius maximum likelihood technique [Cheung and Lai, 1993] and the PcFiml version 9.10 [Doornik and Hendry, 1997]. The first stage of this procedure is to estimate an unrestricted VAR model in the reduced form, where all variables in the system are explained in terms of their own lagged values. In this step, all variables are treated as endogenous and no a priori structural restriction is imposed. For comparative purposes, the number of lags in the VAR model was set the same in all systems (1)-(6). Taking into account the usual information criteria, the PcFiml $F$-tests for system reduction and also the practice in previous exercises using this sample [Brand and Cassola, 2004; Coenen and Vega, 2001], the lag-length was set equal to 2 . The algorithm then factorises this VAR model and tests the number of distinct cointegrating vectors. The trace tests for the number of cointegrating vectors are displayed in Part I of Table $1 .^{4}$

Part II of Table 1 displays the estimated coefficients of the normalised cointegrating vector describing the money demand, as well as the correspondent standard errors. The standard errors can be used for inference regarding individual coefficients, using Wald tests, which are asymptotically distributed as $\chi^{2}(1)$. As a special case, a zero restriction on a particular coefficient may be assessed by comparing the corresponding $t$-ratio to the usual 5 percent critical level, $1.96 .{ }^{5}$ Parts III and IV of Table 1 display the coefficients of other identified co-integrating relationships, when applicable. Part V of Table 1 displays 
TABLE 1

Johansen-Juselius Estimates

\begin{tabular}{|c|c|c|c|c|c|c|}
\hline System & $(1)$ & $\overline{(2)}$ & $(3)$ & $(4)$ & $(5)$ & $(6)$ \\
\hline \multicolumn{7}{|c|}{ I. Trace for reduced rank } \\
\hline$r=0$ & $33.3^{*}$ & $53.2 *$ & $69.7^{* *}$ & $92.9 * *$ & $90.43 * *$ & $118.1^{* *}$ \\
\hline$r \leq 1$ & 13.5 & 25.3 & $32.3^{*}$ & $52.4^{*}$ & $54.6^{* *}$ & $73.6^{*}$ \\
\hline$\leq 2$ & 1.0 & 10.9 & 13.9 & 26.5 & 27.3 & 42.96 \\
\hline$r \leq 3$ & - & 0.1 & 2.1 & 12.3 & 13.5 & 26.8 \\
\hline \multicolumn{7}{|c|}{$\begin{array}{l}\text { II. Estimates of long run coefficients in the money demand equation (standard errors in } \\
\text { parentheses) }\end{array}$} \\
\hline$m$ - real money & -1 & -1 & -1 & -1 & -1 & -1 \\
\hline$y-\mathrm{re}$ & $\begin{array}{l}1.30^{* *} \\
(0.048)\end{array}$ & $\begin{array}{r}1.40 * * \\
(0.056)\end{array}$ & $\begin{array}{l}1.30 * * \\
(0.040)\end{array}$ & $\begin{array}{r}1.37^{* * *} \\
(0.050)\end{array}$ & $\begin{array}{r}1.35^{* *} \\
(0.034)\end{array}$ & $\begin{array}{r}1.39 * * \\
(0.044)\end{array}$ \\
\hline $\begin{array}{l}\text { - euro-area } \\
\text { long-term } \\
\text { interest rate }\end{array}$ & $\begin{array}{l}-0.0057^{* *} \\
(0.0022)\end{array}$ & $\begin{array}{l}-0.0083^{* * *} \\
(0.0028)\end{array}$ & $\begin{array}{c}-0.0062^{* *} \\
(0.0020)\end{array}$ & $\begin{array}{l}-0.0085^{* * *} \\
(0.0025)\end{array}$ & $\begin{array}{c}-0.0025 \\
(0.0016)\end{array}$ & $\begin{array}{l}-0.0087^{* * *} \\
(0.0022)\end{array}$ \\
\hline $\begin{array}{l}j \text { - US long-term } \\
\text { interest rate }\end{array}$ & & $\begin{array}{l}0.0098^{* *} \\
(0.0035)\end{array}$ & & $\begin{array}{l}0.0083^{* *} \\
(0.0031)\end{array}$ & & $\begin{array}{l}0.0098 * * \\
(0.0027)\end{array}$ \\
\hline \multicolumn{7}{|c|}{ III. Equation for the long-term interest rate (standard errors in parentheses) } \\
\hline $\begin{array}{ll}i & \text { - euro-area } \\
\text { long-term } \\
\text { interest rate }\end{array}$ & - & - & -1 & -1 & -1 & -1 \\
\hline $\begin{array}{l}\tau \text { - euro-area } \\
\text { inflation rat }\end{array}$ & - & - & $\begin{array}{r}1.54 * * \\
(0.112)\end{array}$ & $\begin{array}{c}1.69^{* *} \\
(0.109)\end{array}$ & $\begin{array}{r}1.64^{* * *} \\
(0.099)\end{array}$ & $\begin{array}{c}1.73^{* *} \\
(0.0027)\end{array}$ \\
\hline \multicolumn{7}{|c|}{ IV. Stable spread between the long-term and the short-term interest rates } \\
\hline & - & - & - & - & -1 & -1 \\
\hline & - & - & - & - & 1 & 1 \\
\hline \multicolumn{7}{|c|}{ V. Test on the linear restrictions impose } \\
\hline LR statisti & - & - & 0.15 & 0.13 & 2.94 & 5.83 \\
\hline & - & - & 1 & 2 & 3 & 5 \\
\hline$P$-value & - & - & 0.70 & 0.93 & 0.40 & 0.32 \\
\hline
\end{tabular}

Notes: *(**) means significant at the 5 percent (1 percent) level.

Variables used: (1): $m, y, i$; (2): $m, y, i, j ;$ (3): $m, y, i, \pi$; (4): $m, y, i, j, \pi ;(5): m, y, i, s, \pi ;(6): m, y, i, j, s, \pi$. $m$ - Seasonally adjusted real M3 in the euro-area (logs).

$y$ - Seasonally adjusted real GDP in the euro-area (logs).

$i$ - 10-year government bonds yields in the euro-area.

$j-10$-year government bonds yields in the U.S.

$s$ - Short-term interest rate in the euro-area.

$\pi$ - Euro-area inflation rate.

the likelihood ratio (LR) test for the joint restrictions used to identify the long run relationships displayed in Parts II-IV.

Column (1) of Table 1 displays the estimation results of a system consisting on the variables $m, i$, and $y$, only. The trace test for reduced rank suggest the existence of a unique cointegrating vector at the 95 percent level. The parameters of the cointegrating vector representing the money demand are reported in Part II of Table 1. This 
cointegrating vector relates real balances to real income and the domestic long-term interest rate, as in a closed economy. The estimated income elasticity is 1.3 and the Wald test for a unit income elasticity gives a $\chi^{2}(1)$ test value of $38.1\left([(1.3-1.0) / 0.048]^{2}\right)$, indicating rejection at the 1 percent significance level. Rejection of unit income elasticity is common to estimates (1)-(6) and is in accordance to the previous literature on euroarea money demand [Brand and Cassola, 2004; Fase and Winder, 1998]. The semielasticity of the domestic interest rate is negative, as expected, and significant at the 1 percent level.

Column (2) displays the estimation results of a system containing all the variables included in equation (1). The trace statistic suggests the existence of a unique cointegrating vector at the 5 percent significance level. The coefficients of the normalised co-integrating vector (in Part II) have signs in accordance to the theory. Remarkably, the semi-elasticity of the foreign interest rate is of a similar magnitude to that of the domestic interest rate. All $t$-ratios suggest statistical significance. In particular, the LR test for the hypothesis of 'no CS', $\beta_{2}=0$, indicates rejection at the 1 percent significance level.

System (3) expands system (1) by including the euro-area inflation rate among the regressors. As expected, the trace test for reduced rank now suggests the existence of two co-integrating vectors at the 5 percent significance level. Following the recent literature, two long-run relationships were identified: One for the money demand relationship (Part II) and a second for a relationship involving the nominal interest rate and the inflation rate (Part III). Regarding the later, Coenen and Vega [2001] were able to identify a Fisher equation - that is, a co-integrating vector for $l$ and $\pi$, with parameters $[-1,1]$. In the Brand and Cassola sample (our sample), however, a positive relationship between inflation and the real interest rate holds instead. ${ }^{6}$ The signs of the money demand coefficients are in accordance to the closed economy model of money demand and the $t$ ratios suggest significance. The LR test statistic for the identifying restrictions in model (3) is 70 percent.

Column (4) expands system (3) by including the U.S. dollar long-term interest rate. The trace statistics suggest again the existence of two cointegrating vectors at the 5 percent significance level, which are identified as in (3) (according to our estimates, there is no stable relationship between the U.S. and the euro-area interest rates). The $P$-value of the LR-test for the identifying restrictions is now 93 percent (column 4, Part V) and its recursive estimation suggests that these restrictions are valid throughout the sample period (results of recursive estimation are available from the author upon request). The money demand coefficients are again in accordance to equation (1) and the implied $t$ ratios suggest significance. As in (2), the hypothesis of 'no CS' is rejected at the 1 percent significance level.

Columns (5) and (6) expand (3) and (4) by including the money market interest rate $(s)$ among the regressors. Noticeably, in system (5) the null hypothesis of 'at most two cointegrating vectors' is rejected at the 10 percent significance level, only. In system (6), this assumption is not rejected. Eventually, this reflects loss of power of the trace statistic due to the increasing number of parameters in the model. In both cases, however, we proceed identifying three long-run relationships: The money demand (Part II); the positive relationship between inflation and the long-term interest rate (Part III); and a stable 'spread' between the long-term interest rate and the short-term interest rate (Part IV). ${ }^{7}$ As before, the foreign interest rate gets a positive and significant coefficient when included in the money demand equation (system 6). The domestic interest rate coefficient, in turn, is only significant when the foreign interest rate is also 
included in the system. The $P$-values of the LR tests for the identifying restrictions are 40 percent in (5) and 32 percent in (6), indicating a weaker performance relative to systems (3)-(4).

Comparing the performances of models (1)-(6), we observe the following. First, the coefficient of the foreign interest rate gets a positive and significant sign across equations. This evidence accords to the theoretical model underlying equation (1) and is suggestive of euro-dollar substitution. Second, the estimated semi-elasticity of the domestic interest rate is relatively stable across systems where the foreign interest rate is included, but it varies substantially across systems where the foreign interest rate is omitted. This suggests that the omission of the foreign interest rate from the VAR system involves a misspecification error. If that is so, then this problem will be affecting all recent estimates addressing the euro-area money demand [Brand and Cassola, 2004; Funke, 2001; Coenen and Vega, 2001; Hayo, 1999; Fagan and Henry, 1999; Spencer, 1997]. Third, when the U.S. dollar interest rate is included among the regressors, the magnitude of its coefficient becomes similar to that obtained for the domestic interest rate. This suggests that monetary disturbances abroad impact the euro-area money demand with a magnitude similar to that of financial disturbances occurring at home. Finally, the model is not likely to benefit from the presence of the domestic money market interest rate $(s)$ among the regressors.

From the policy point of view, it might be interesting to compare not only the magnitudes of the semi-elasticities of the domestic and foreign interest rates, but also the time it takes for the money demand to adjust to shocks in these two variables. To address this question, Figure 1 reports generalized impulse response functions for model (4). It should be noted that these functions [Pesaran and Shin, 1998] do not convey information about structural relationships among variables. They shall simply be thought as tracing out how a given endogenous variable - in this case, the money demand-will deviate from the path predicted by the estimated model, following a one-time shock to each one of the possible innovations in the system. According to Figure 1, if, for some reason, the euro-area long-term interest rate is one standard error above what the model would have predicted, this will initially lead to a downward revision in the money demand forecasts. However, as the shock is transmitted to the other variables in the system, there will be feed-back effects that, after accounted for, turn out the long-term forecast of the money demand to be above what the model would have initially predicted. According to the figure, it takes roughly 12 quarters for the money demand to almost fully adjust to a onetime shock in the domestic interest rate. Noticeably, it takes a similar length of time for the money demand to adjust to a one-time shock in the U.S. dollar long-term interest rate. It is also worth nothing that, in the later case, half of the adjustment in the money demand relationship is completed after six quarters. This suggests that monetary developments in the U.S. may have substantial short-run effects in the euro-area.

\section{Final Remarks}

In this paper, we test the stability of a money demand equation for the euro-area, experimenting different combinations of variables in the vector auto-regressive system. We consistently find a significant and positive coefficient for the U.S. dollar long-term interest rate in the European money demand relationship. Although this result may be supportive of currency substitution, it may also be a consequence of other channels through which monetary developments in the U.S. affect real money demand in Europe. For example, it could be that European monetary authorities responded to changes in U.S. interest rates or to changes in other variables influenced by U.S. interest rates by 
Response to Generalized One S.D. Innovations
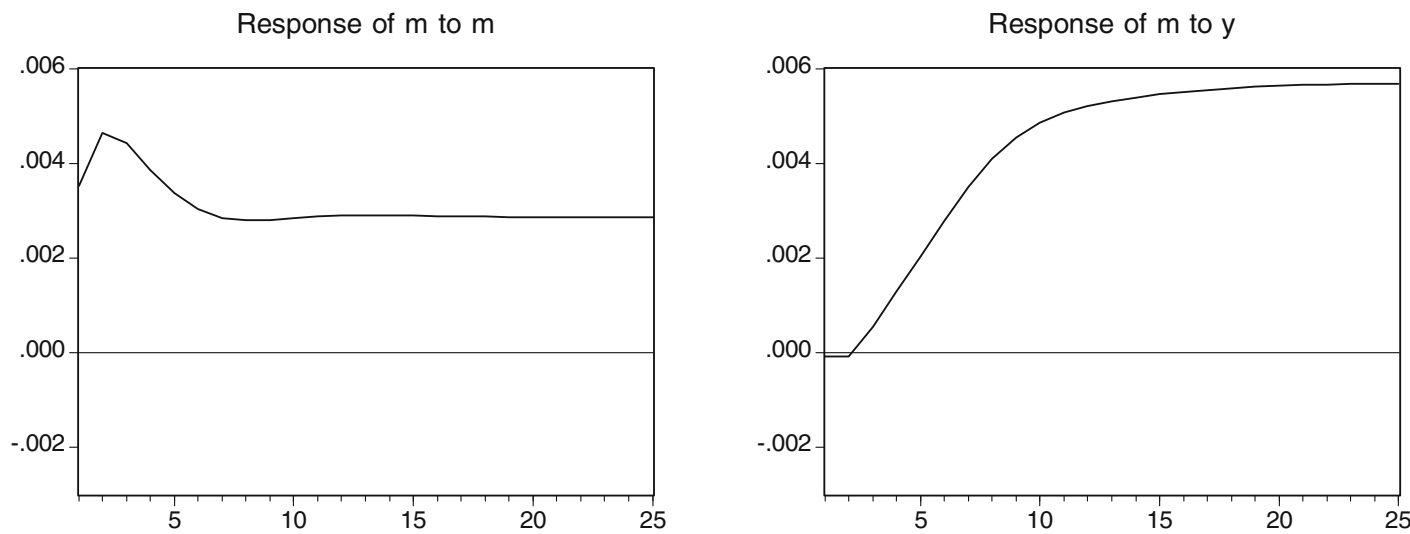

Response of $\mathrm{m}$ to $\mathrm{i}$
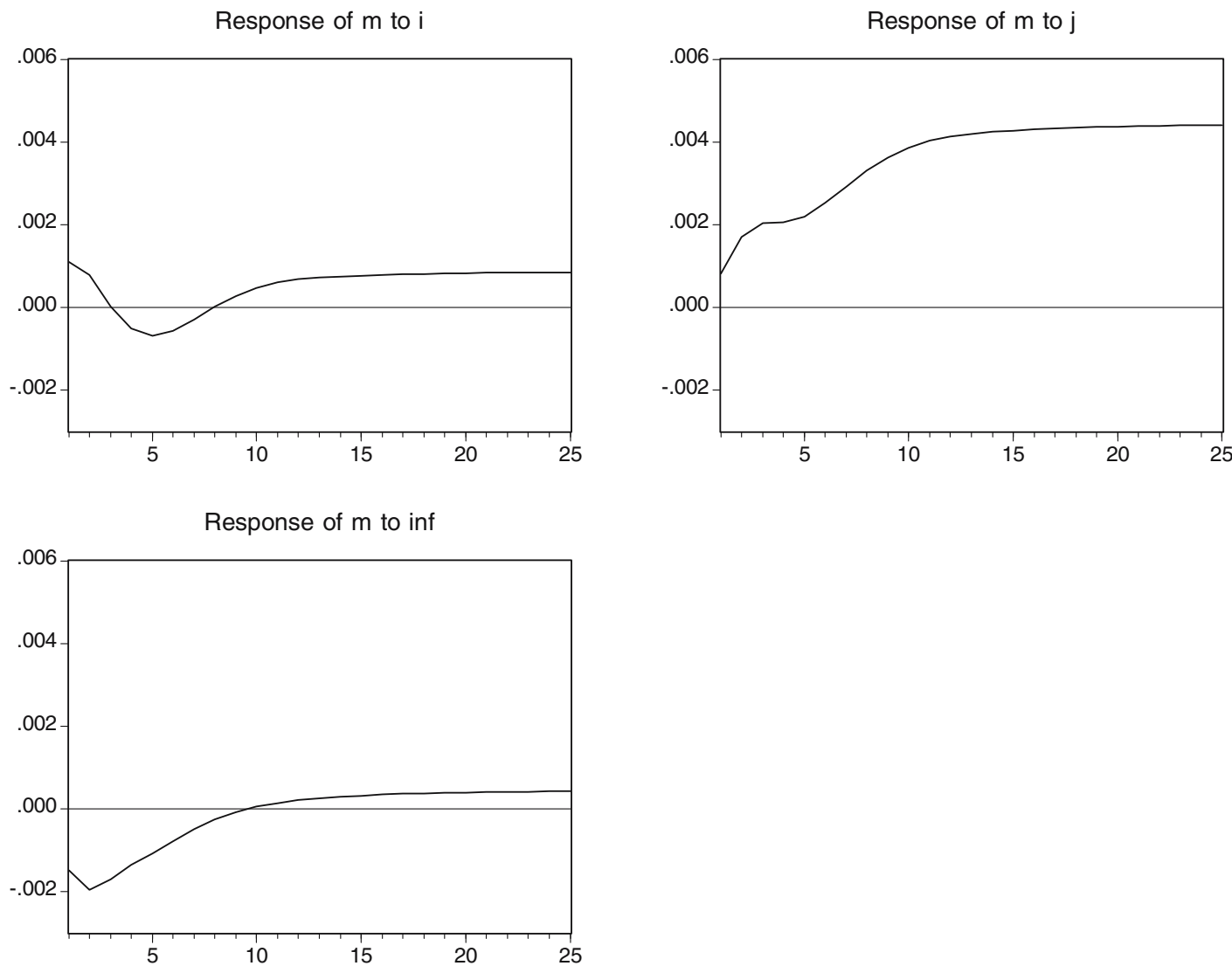

Figure 1. Generalized Response Profiles: All Variables to $m$ (Model 4).

adjusting the money supply. Whatever the link is, this does not change the main conclusion of this paper that interdependence matters.

The exercise implemented in this paper shares with the previous literature the limitation of being based on constructed pre-EMU monetary aggregates. In light of the Lucas critique, the coefficients estimated above may have little value for forecasting and 
policy prescription. The aim of the exercise is not, however, to defend particular elasticity values for the money demand equation so as to justify any money supply rule. On the contrary, by stressing the interdependent nature of the international monetary system, we add an argument to the general case for caution in the interpretation of the information content of EU-wide monetary aggregates.

Since the euro-area is a larger and relatively more closed economy than any of the participating countries, there was a view that it should be mainly affected by domestic shocks rather than by monetary developments abroad. By stressing the influence of the U.S. dollar interest rate in the euro-area money demand, the results obtained in this paper challenge this 'de-coupling' view of the European monetary unification. In particular, the results question the usefulness of announcing reference values for the rate of monetary expansion, irrespective as to whether the Federal Reserve is expanding or tightening the monetary policy.

Looking behind, the experience in the first years of operation with the euro reveals that the 'first pillar' has lost much of its original prominence. In the absence of major risks to price stability, money has been allowed to expand at faster rates than announced. Although the information content of the money aggregate M3 and some of its components still plays an important role in the ECB policy formulation, since May 2003 , the reference value for the growth rate of M3 is no longer being reviewed on a annual basis [ECB, 2003]. This evolution is not at odds to what happened in the U.S. In that country, annual ranges for monetary expansion were actually maintained until June 2000, when the law requirement expired. However, the public was aware that these targets played almost no role in deliberations since the mid-1980s [Parry, 2000].

The results of this study may also give an insight for the current debate on the future of the international monetary system. As many authors have been arguing, the increasing international monetary inter-dependence may call for coordination of monetary policies [Mckinnon, 2000]. Prior to the EMU, the dollar played a prominent role in the international monetary system. There was some move towards diversification following the collapse of Bretton Woods, but the hegemony of the dollar as international currency was maintained [for the roles of international currencies, see Krugman, 1984]. With the advent of the EMU, the asymmetry of the international monetary system was substantially reduced. As the euro becomes comparable to the dollar both in terms of credibility and liquidity, the substitutability between these two currencies may become higher than between any other pair of international currencies before. This means that, not only shocks in the international monetary system affecting the total demand for international money will impact on the respective money demands, but also shocks affecting the relative demand for international currencies. The evidence presented in this paper suggests that this second mechanism was already in place before the launch of the euro. Whether the likely increasing currency competition will raise the instability of the international monetary system, as argued by McKinnon [1982, 2000] or will act instead as a disciplinary device, as argued by Yeager [2004], is something that certainly deserves further investigation.

\section{Footnotes}

${ }^{1}$ Whether this 'indirect approach' provides evidence of intra-European CS is a different question. As noted, for example, by Fagan and Henry [1999], the superiority of EU-wide estimates can be attributed either to a statistical averaging effect or to asymmetric shocks that offset each other in the aggregate, of which intra-European CS is a only special case. For direct tests suggesting the existence of intra-European currency substitution, see Melvin [1985]. 
${ }^{2}$ The case with restrictions on foreign bond holdings is analysed in Lebre de Freitas and Veiga [2006].

${ }^{3}$ Although ECB data is available from 1980:1, our experiments revealed that the quality of the fit improves significantly after removing the first observations of the sample (coincidentally, both Coenen and Vega, 2001, and Brand and Cassola, 2004, reported outliers in the beginning of the sample).

${ }^{4}$ As in both Brand and Cassola [2004] and Coenen and Vega [2001], a minor problem of residual non-normality was detected across systems. For this reason, co-integration is evaluated only on the basis of the trace test, which is likely to be more robust to some forms of non-normality than the maximal eigenvalue test [Cheung and Lai, 1993].

${ }^{5}$ Denoting by $\beta$ the estimated coefficient and by $\sigma$ the standard error, the Wald test is $t^{2}=(\beta / \sigma)^{2} \sim \chi^{2}(1)$. The square root of the 5 percent critical level $\chi_{0.95}^{2}(1)=3.84$ is 1.96 .

${ }^{6}$ Brand and Cassola [2004] interpreted this as an equilibrium relationship, due to the impact of taxation. A simpler reasoning, however, can be found on the basis of a sample peculiarity. In the 1980 s, interest rates were initially high, due to the widespread use of capital controls, high public debt in some countries and restrictive monetary policies. During the transition to EMU, in a context of progressive elimination of capital controls and healthier public finance, interest rates were allowed to decline as inflation fell. This translates into a positive relationship between inflation and the real interest rate in this particular sample, but it does not mean that such relationship can be used to forecast inflation or interest rates in the future.

${ }^{7}$ Alternatively, one may identify two co-integrating vectors only: One for the money demand and the other for an unrestricted relationship involving the long-term interest rate, the short-term interest rate, and the inflation rate. The corresponding results (available upon request) do not differ qualitatively from those displayed in columns (5)-(6).

\section{References}

Arnold, I. J. "The Myth of a Stable European Money Demand," Open Economies Review, 5, 3, July 1994, pp. $249-259$.

Arnold, I. J.; de Vries, C. G. "Endogeneity in European Money Demand," European Journal of Political Economy, 16, 4, November 2000, pp. 587-609.

Artis, M. "Currency Substitution in European Financial Markets," in: P. Mizen, E. J. Pentecost eds., The Macroeconomics of International Currencies: Theory, Policy and Evidence, Cheltenham, UK: Edward Elgar, 1996, pp. 139-154.

Bayoumi, T. A.; Kenen, P.B. "How Useful is an EC-Wide Monetary Aggregate as an Intermediate Target for Europe?" Review of International Economics, 1, 3, 1993, pp. 209-220.

Bekx, P.; Tullio, G. "A Note on the European Monetary System and the Determination of the DMDollar Exchange Rate," Caiers Economiques de Bruxelles, 123, 1989, pp. 329-343.

Bergstrand, J. H.; Bundt, T. P. "Currency Substitution and Monetary Autonomy: The Foreign Demand for US Deposits," Journal of International Money and Finance, 9, 3, September 1990, pp. $325-334$.

Beyer, A.; Doornik, J. A.; Hendry, D. F. "Constructing Historical Euro-Zone Data," The Economic Journal, 111, 469, February 2001, pp. F102-F121.

Brand, C.; Cassola, N. "A Money Demand System for Euro Area M3," Applied Economics, 36, 8, May 2004, pp. 817-838.

Branson, W. H.; Henderson, D. W. "The Specification and Influence of Asset Markets," in: R. W. Jones, P. B. Kenen eds., Handbook of International Economics, Vol. II, Amsterdam: North Holland, 1985, pp. 749-805.

Browne, F.; Fagan, G.; Henry, J. "Money Demand in EU Countries: A Survey," European Monetary Institute Staff Paper 7, Frankfurt, March 1997.

Cassard, M.; Lane, T. D.; Masson, P. R. "ERM Money Supplies and the Transition to EMU," International Monetary Fund Working Paper, 94/1, January 1994.

Cheung, Y.-W.; Lai, K. S. Y. "Finite Sample Sizes of Johansen's Likelihood Ratio Tests for Cointegration," Oxford Bulletin of Economics and Statistics, 55, 3, 1993, pp. 313-328. 
Coenen, G.; Vega, J. L. "The Demand for M3 in the Euro Area," Journal of Applied Econometrics, 16, 6, November-December 2001, pp. 727-748.

Cuddington, J. T. "Currency Substitutability, Capital Mobility and Money Demand," Journal of International Money and Finance, 2, 2, August 1983, pp. 111-133.

Doornik, J.; Hendry, D. F. "Modelling Dynamic Systems Using PcFiml 9 for Windows," International Thomson Business 1997.

ECB "The Stability Oriented Monetary Policy Strategy of the Eurosystem," ECB Monthly Bulletin, January 1999, pp. 41-53.

-. "The Outcome of the ECB's Evaluation of its Monetary Policy Strategy," ECB Monthly Bulletin, June 2003, pp. 79-92.

Fagan, G.; Henry, J. "Long Run Money Demand in the EU: Evidence for Area-Wide Aggregates," in: Helmut Lutkepohl, Jurgen Wolters eds., Money Demand in Europe, Heidelberg: Physica Verlag, 1999, pp. 217-240.

Fase, M.; Winder, C. "Wealth and the Demand for Money in the European Union," Empirical Economics, 23, 3, 1998, pp. 507-524.

Funke, M. "Money Demand in Euroland," Journal of International Money and Finance, 20, 5, October 2001, pp. 701-713.

Giovannini, A.; Turtelboom, B. "Currency Substitution," in: Frederick Van Der Ploeg ed., The Handbook of International Macroeconomics, Oxford, UK: Blackwell, 1994, pp. 390-436.

Hayo, B. "Estimating a European Demand for Money" The Scottish Journal of Political Economy, 46, 3, August 1999, pp. 221-244.

Issing, O. "The ECB's Monetary Policy: Experience after the First Year," Journal of Policy Modelling, 22, 3, May 2000, pp. 325-343.

Kareken, J.; Wallace, N. "On the Indeterminacy of Equilibrium Exchange Rates," Quarterly Journal of Economics, 96, 2, 1981, pp. 207-222.

Kremers, J. J.; Lane, T. D. "Economic and Monetary Integration and the Aggregate Demand for Money in the EMS," International Monetary Fund Staff Papers, 37, 4, December 1990, pp. 777-805.

Krugman, P. "The International Role of the Dollar: Theory and Prospect," in: J. F. Bilson, R. C. Martson eds., Exchange Rate in Theory and Practice, Chicago: University of Chicago, 1984, pp. 261-278.

Lebre de Freitas, M. "The Dynamics of Inflation and Currency Substitution in a Small Open Economy," Journal of International Money and Finance, 23, 1, February 2004, pp, 133-142.

Lebre de Freitas, M.; Veiga, F. "Currency Substitution, Portfolio Diversification and the Money Demand," Forthcoming, Canadian Journal of Economics, 39, 3, August 2006.

Masson, P. Remarks on "One World, One Currency: Destination or Delusion?" Speech at the IMF Economic Forum, November 8. Transcript available in http://www.imf.org/external/np/tr/2000/ tr001108.htm 2000.

McKinnon, R. "Currency substitution and the instability in the world dollar standard," American Economic Review, 72, 3, June 1982, pp. 320-333.

-. "Mundell, the Euro and the World Dollar Standard," Journal of Policy Modeling, 22, 3, May 2000, pp. 311-324.

Melvin, M. "Currency substitution and Western European Monetary unification," Economica, 52 February 1985, pp. 79-91.

Miles, M. A. "Currency Substitution, Flexible Exchange Rates, and Monetary Independence," American Economic Review, 68, 3, June 1978, pp. 428-436.

Mizen, P.; Pentecost, E. J. "Evaluating the Empirical Evidence for Currency Substitution: A Case Study of the Demand for Sterling in Europe," The Economic Journal, 104, September 1994, pp. 1057-1069.

Monticelli, C.; Strauss-Kahn, M.-O. "European Integration and the Demand for Broad Money," Manchester School of Economics and Social Studies, 61, 4, 1993, pp. 345-366.

Parry, R. "Monetary policy in a new environment: The US experience" manuscript, presented in the Bundesbank/BIS conference on Recent Developments in Financial Systems and their Challenges for Economic policy: A European Perspective, Frankfurt, September 2000. 
Pesaran, H. H.; Shin, Y. "Generalized impulse response analysis in linear multivariate models," Economics Letters, 58, 1, January 1998, pp. 17-29.

Spencer, P. "Monetary Integration and Currency Substitution in the EMS: The case for a European Monetary Aggregate," European Economic Review, 41, 7, July 1997, pp. 1403-1419.

Thomas, L. R. "Portfolio Theory and Currency Substitution," Journal of Money, Credit and Banking, 17, 3, August 1985, pp. 347-357.

Yeager, L. B. "The Euro Facing other Monies," Cato Journal, 24, 1-2, Spring/Summer 2004, pp. 27-40. 